\title{
Comparative Study on Minerals in Peel and Pulp of Peach (Prunus persica L.) Fruit
}

\begin{abstract}
SNEZANA MITIC, BRANKA STOJ ANOVIC, SNEZANA TOSIC*, ALEKSANDRA PAVLOVIC, DANIJ ELA KOSTIC, MILAN MITIC
University of Nis, Faculty of Sciences and Mathematics, Department of Chemistry, Visegradska 33, 18000 Nis, Serbia

In this study, variations of minerals contents between peel and pulp parts of six different peach varieties originated from Serbia were investigated by using inductively coupled plasma optical emission spectrophotometry and one-way analysis of variance (ANOVA) with Tukey's post-hoc test. The content of fifteen elements was determined and content of $K$ was highest among macroelements and Fe among microelements in both parts of the peach fruit. Also, peach peel had higher levels of all minerals with the exception of K. Greater differences between the peel and the pulp and the same parts of different types of peaches are observed in the case of macroelements than the microelements. $\mathrm{Hg}$ and $\mathrm{Cd}$ are not detected while the contents of $\mathrm{Pb}$ and $\mathrm{As}$ are below prescribed values.
\end{abstract}

Keywords: peach, minerals, ICP-OES determination, statistical analysis

Peaches are classified as Prunus persica L. and belong to the Rosaceae family. Its fruits with golden yellowish flesh are one of a favorite that are used in diet because of their refreshing sour-sweet taste. Natural sugars, organic acids, phenolic acids, vitamins ( $C$ and $A$ ), flavonoids and anthocyanin compounds, minerals and dietary fibers are among the major constituents of peach fruits, which contribute to the nutritional quality of both fresh fruits and the juices i.e. these constituents certainly elevate the nutritional status of the peach fruit. $100 \mathrm{~g}$ portion of peach fruits should have $165 \mathrm{~kJ} ; 0.91 \mathrm{~g}$ of protein; $0.25 \mathrm{~g}$ of total lipid; 9.54 of carbohydrate; $8.39 \mathrm{~g}$ of sugars; $1.5 \mathrm{~g}$ of dietary fiber; $6.6 \mathrm{mg}$ of vitamin C; $88.9 \mathrm{~g}$ of water etc. [1]. Dietary intake of peach can reduce the generation of reactive oxygen species and provide protection from several chronic diseases. Many published reports reveal that peel of various fruits (apple, persimmons, pear) contains higher amount of phenolics and flavonoids as compared to their flesh parts $[2,3]$.

The plants translocate some quantities of metals from soil, water and air to their roots, trees, branches, leaves, fruits and seeds. Many factors affect the bioavailability of metals: the total metal soil concentration, $\mathrm{pH}$, the organic matter content, redox conditions, etc. Also, the plant genotype is the most important factor affecting the metals adoption [4]. Healthy plant growth requires not only macronutrients ( $\mathrm{N}, \mathrm{P}, \mathrm{K}, \mathrm{S}, \mathrm{Ca}$, and $\mathrm{Mg}$ ) but also micronutrients such as $\mathrm{Co}, \mathrm{Cu}, \mathrm{Fe}, \mathrm{Mn}, \mathrm{Mo}, \mathrm{Ni}$, and $\mathrm{Zn}$ which are essential for plant metabolism in trace amounts [5]. Some of necessary microelements may interfere with physiological processes and could be harmful for plants and may affect human health when they are present at excessive levels [6]. The assessment of metals content, especially heavy metals, in fruits is an important issue with regards to human health and represents one of the factors in the evaluation of their quality.

Extensive use of fertilizers, inorganic and livestock manures (e.g. cattle, sheep, poultry, etc.), metal-based pesticides, insecticides and herbicides play an important role in increasing the mineral contents of soils and plant tissues. Also, the polluted environment, the fuel combustion, contaminated food transport and supply chains, poor market sanitary conditions and the use of contaminated or waste water for irrigation purposes, may contribute to the increased content of heavy metals in food.
The different chemical compounds used to supply N, P, and $\mathrm{K}$ for plant growth contain trace amounts of heavy metals as impurities. Pesticide, insecticides and fungicides were based on compounds which contain $\mathrm{Cu}, \mathrm{Hg}, \mathrm{Pb}$, or $\mathrm{Zn}$. Cd is found predominantly in phosphoric fertilizers and Fe in some inorganic fertilizers which are regularly added to soil $[5,7]$. Matei et al. found that over a period of six years, the concentration of $\mathrm{Cd}$ is increased twenty times because of fuel combustion from highway and town which can be the major pathway trough $\mathrm{Cd}$ is released into the atmosphere [3].

Nutrient levels in foods are variable. In the case of fruits, mineral levels can be affected by factors such as the variety of the produce item, time of harvest, ripeness, climate, soil conditions including fertilizer application, and storage and marketing conditions. There are a lot of literature data about minerals contents of whole peaches fruit. Matei et al. determined $\mathrm{Cd}, \mathrm{Cu}, \mathrm{Zn}$, and $\mathrm{Pb}$ in fresh fruits [3]. The most abundant heavy metal was $\mathrm{Cu}\left(2.47 \mathrm{mg} \mathrm{kg}^{-1}\right)$, followed by Zn (1.5236 mg kg-1) and Cd $\left(0.0228 \mathrm{mg} \mathrm{kg}^{-1}\right)$ while $\mathrm{Pb}$ was not detected. All determined contents are below the recommendable maximum limits for metals in fruits: $0.05 \mathrm{mg} \mathrm{kg}^{-1}$ for $\mathrm{Cd}$; $0.1 \mathrm{mg} \mathrm{kg}^{-1}$ for Pb and $5 \mathrm{mg} \mathrm{kg}^{-1}$ for $\mathrm{Cu}$ and $\mathrm{Zn} \mathrm{[8].} \mathrm{Radwan} \mathrm{and} \mathrm{Salama} \mathrm{analyzed} \mathrm{dried}$ peaches samples from Egyptian markets and found elevated values: $0.38 \mathrm{mg} \mathrm{kg}^{-1} \mathrm{~Pb}, 6.22 \mathrm{mg} \mathrm{kg}^{-1} \mathrm{Zn}, 0.01 \mathrm{mg}$ $\mathrm{kg}^{-1} \mathrm{Cd}$ and $1.46 \mathrm{mg} \mathrm{kg}^{-1} \mathrm{Cu}$ [ 7]. Peach samples of one area in Libya contain $1.87 \mathrm{mg} \mathrm{kg}^{-1} \mathrm{Cu} ; 5.87 \mathrm{mg} \mathrm{kg}^{-1} \mathrm{Zn}$ and 0.02 $\mathrm{mg} \mathrm{kg}^{-1} \mathrm{Cd}$ [9]. Ashhammary and Al-Horayess, determined minerals concentrations in peaches of the three major agricultural Saudi companies and their results show that Fe is dominant $\left(176.33 \mathrm{mg} \mathrm{kg}^{-1}\right)$, followed by $\mathrm{Ca}$ ( 150.33 $\left.\mathrm{mg} \mathrm{kg}^{-1}\right) ; \mathrm{Mg}\left(25.47 \mathrm{mg} \mathrm{kg}^{-1}\right) ; \mathrm{Cu}\left(19.93 \mathrm{mg} \mathrm{kg}^{-1}\right) ; \mathrm{Zn}$ (12.74 $\left.\mathrm{mg} \mathrm{kg}^{-1}\right) ; \mathrm{Mn}\left(9.24 \mathrm{mg} \mathrm{kg}^{-1}\right)$ and $\mathrm{Cd}\left(0.099 \mathrm{mg} \mathrm{kg}^{-1}\right.$ ) (DW) [5]. Cunningham et al. detected $230 \mathrm{mg} 100 \mathrm{~g}^{-1} \mathrm{~K} ; 1 \mathrm{mg}$

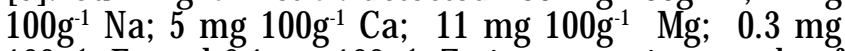

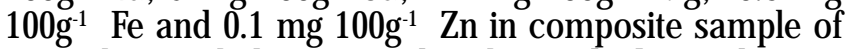
several unpeeled row peach cultivars [10]. Peach juice and peach nectar samples are often the subject of metals contents determination [11,12].

Component parts of the peach fruit, namely flesh or pulp and peel, are not much studied [2,13]. The objective of present work was to compare elemental composition among pulp and peel of the various peach cultivars from Serbia as well as to compare obtained values with the 
established national and international standards and recommendations. Optical emission spectrometer with inductively coupled plasma (ICP-OES) as a multi-element technique for the detection of major, minor and trace elements in different complex samples which combines qualities such as a relatively low detection limits, high capacity for the simultaneous and precise detection for short intervals over wide concentration ranges, was used for this purpose.

\section{Experimental part}

Materials and methods

Sample collection and preparation

The analyzed six varieties of peaches (Radmilovcanka and Vesna as domestic cultivars; J une Gold; Blake; Hale and Adria as cultivars from American continent) originated from Southeast Serbia (district of Niš) orchards which are approximately the same age without significantagricultural measures and with the same type of soil. Fully ripened fresh fruits of the five randomly selected trees were collected at the peak of the harvest period during J uneSeptember 2013. depending on the varieties. Samples were transported in closed polyethylene bags, washed thoroughly first by tap water followed by acidified and deionized water and peeled to separate pulp and peel. The homogenized composite samples (about $10 \mathrm{~g}$ ) were frozen until dry-digested mineralization process in furnace with the controlled temperature in the range from 500 to $450 \mathrm{o} \mathrm{C}$ for $24 \mathrm{~h}$. After the complete digestion the cooled dry residues were dissolved in $2.5 \mathrm{ml} \mathrm{HNO3} \mathrm{(1:1,} \mathrm{v/v),}$ filtered through Whatman No. 42 filter paper and transferred to a $50 \mathrm{ml}$ volumetric flask with deionized water [14]. All necessary measures of contamination prevention were taken at all steps in process.

\section{Instrumentation}

The iCAP 6000 inductively coupled plasma optical emission spectrometer which combines an Echelle optical design and a charge injection device (CID) solid state detector (Thermo Scientific, Cambridge, United Kingdom) was used for analysis the metals contents. Analyses were made in triplicate and the mean values are reported. The blank sample involving the addition of all used reagents except sample was also processed to make corrections during calculation of elemental concentrations. ITEVA operating software series was used to control all functions of the instrument. Analytical balance Mettler Toledo (Switzerland) was used to measure the mass. High purity water (conductivity $0.05 \mu \mathrm{S} \mathrm{cm}^{-1}$ ) was obtained using MicroMed high purity water system, Thermo Electron LED $\mathrm{GmbH}$ (Germany). Under the optimal operating conditions for the instrument (radio frequency power-1150 W; analysis pump rate- $50 \mathrm{rpm}$; flush pump rate-100 rpm; nebulizer gas flow- $0.7 \mathrm{~L} \mathrm{min-1;} \mathrm{coolant} \mathrm{gas} \mathrm{flow-} 12 \mathrm{~L} \mathrm{~min}{ }^{-1}$

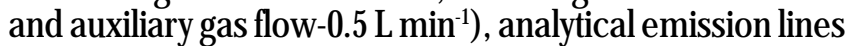
for each of the element were selected based upon the tables of known interferences, baseline shifts and the background correction (the highest signal-to-background ratio) which was manually selected for the quantitative measurements.

Reagents

The multi-element standard solution (Ultra Scientific, USA, Item ICM-240, EPA Method 200.7 LPC Solution of 30 analytes) of $20.00 \pm 0.10 \mathrm{mg} \mathrm{L}^{-1}$ was used as a stock solution for calibration. Matrix of multi-standard was $2 \%$ $\mathrm{HNO}_{3}$ with traces of tartaric acid in deionized water with low values of total organic carbon (TOC $<50 \mathrm{mg} \mathrm{L}^{-1}$ ). Analytical grade $65 \%$ nitric acid (Merck, Darmstadt, Germany) was used for complete mineralization of analyzed samples. All the solutions were prepared using high purity deionized water.

Statistical analysis

All ICP-OES measurements were carried out in triplicate, presented as mean \pm standard deviation (SD) and the results were subjected to statistical analysis. One-way analysis of variance (ANOVA) with Tukey's post-hoc test was done to determine significant differences, considering a level of significance of less than $5 \%(p \hat{0} 0.05)$ using a statistical package IBM SPSS 20, US. [15].

\section{Results and discussions}

The determined minerals were classified according to the criteria of the World Health Organization into the following groups: the essential macroelements ( $\mathrm{Na}, \mathrm{K}, \mathrm{Mg}$, $\mathrm{Ca}$, and P) (table 1); essential trace elements and trace elements that are probably essential $(\mathrm{Cr}, \mathrm{Cu}, \mathrm{Fe}, \mathrm{Mn}, \mathrm{Ni}, \mathrm{Zn}$, and B) (table 2) and toxic and potentially toxic-some possibly with essential functions ( $\mathrm{Al}, \mathrm{As}$, and $\mathrm{Pb}$ ) (table 3 ) [16]. All metals contents were calculated on a wet weight basis ( $\left.\mathrm{mg} \mathrm{kg}^{-1} \mathrm{WW}\right)$. Tables with determined elements concentrations also contain the results of one-way analysis of variance with Tukey's post-hoc test.

Macroelements have great significance for the human body: potassium as an element with big role in ionic balance and cell function and it is important for proper cardiac contraction, for the proper functioning of the intestines and muscles; calcium is responsible for the development and growth of bones and teeth; itis necessary for muscle contraction, nerve transfer signal and for secretion of hormones and enzymes; magnesium plays

\begin{tabular}{ccccccc}
\hline Varieties & $\begin{array}{c}\text { Fruit } \\
\text { part }\end{array}$ & $\mathrm{Na}$ & $\mathrm{K}$ & $\mathrm{Mg}$ & $\mathrm{Ca}$ & $\mathrm{P}$ \\
& pulp & $99 \pm 1$ & $4613 \pm 38$ & $80.6 \pm 0.5$ & $141 \pm 2^{\mathrm{a}}$ & $352 \pm 3^{\mathrm{a}}$ \\
& Radmilovcanka & $168 \pm 2$ & $3633 \pm 25$ & $122 \pm 2^{\mathrm{a}}$ & $254 \pm 2$ & $408 \pm 3$ \\
& peel & $117 \pm 2$ & $4028 \pm 45$ & $107.4 \pm 0.7$ & $186 \pm 2$ & $343 \pm 3^{\mathrm{a}}$ \\
June Gold & peel & $228 \pm 2$ & $3437 \pm 31$ & $122 \pm 2^{\mathrm{a}}$ & $203 \pm 2$ & $485 \pm 5^{\mathrm{b}}$ \\
& pulp & $192.3 \pm 0.7$ & $4499 \pm 40$ & $92.1 \pm 0.4^{\mathrm{b}}$ & $157 \pm 2$ & $298 \pm 4^{\mathrm{c}}$ \\
Blake & peel & $274 \pm 2$ & $4034 \pm 35$ & $140 \pm 2$ & $272 \pm 3^{\mathrm{b}}$ & $384 \pm 3^{\mathrm{d}}$ \\
& pulp & $145 \pm 2$ & $1822 \pm 18$ & $87.7 \pm 0.8$ & $145 \pm 2^{\mathrm{a}}$ & $303 \pm 4^{\mathrm{c}}$ \\
Hale & peel & $201 \pm 2$ & $1223 \pm 12$ & $116 \pm 2$ & $272 \pm 3^{\mathrm{b}}$ & $362 \pm 4$ \\
& pulp & $51.8 \pm 0.4$ & $6066 \pm 53$ & $94.2 \pm 0.9^{\mathrm{b}, \mathrm{c}}$ & $119 \pm 2$ & $374 \pm 4^{\mathrm{a}}$ \\
Vesna & peel & $91.1 \pm 0.4$ & $4606 \pm 51$ & $100.2 \pm 0.9$ & $168 \pm 2$ & $478 \pm 6^{\mathrm{b}}$ \\
& pulp & $34.0 \pm 0.4$ & $6605 \pm 49$ & $94.2 \pm 0.8^{\mathrm{c}}$ & $228 \pm 2$ & $368 \pm 5^{\mathrm{c}}$ \\
Adria & peel & $81.5 \pm 0.3$ & $5287 \pm 44$ & $111.8 \pm 0.5$ & $295 \pm 1$ & $393 \pm 4^{\mathrm{d}}$ \\
\hline
\end{tabular}

Table 1

THE CONTENT OF ESSENTIAL MACROELEMENTS $\pm S D^{A}\left(\mathrm{mg} \mathrm{kg}^{-1} \mathrm{WW}\right)$ in PEEL AND PULP PARTS OF PEACH FRUIT

SD-standard deviation for triplicate determination; mean values in the same column with the same small letters indicate no significant differences $(p<0.05)$ between the pulps and between the peels of different cultivars, separately 
Table 2

THE CONTENT OF ESSENTIAL TRACE ELEMENTS $\pm S D^{A}\left(\mathrm{mg} \mathrm{kg}^{-1} \mathrm{WW}\right)$ IN PEEL AND PULP PARTS OF PEACH FRUIT

\begin{tabular}{|c|c|c|c|c|c|c|c|c|}
\hline Varieties & $\begin{array}{c}\text { Fruit } \\
\text { part }\end{array}$ & $\mathrm{Cr}$ & $\mathrm{Cu}$ & $\mathrm{Fe}$ & $\mathrm{Mn}$ & $\mathrm{Ni}$ & $\mathrm{Zn}$ & B \\
\hline & pulp & $0.079 \pm 0.003^{26}$ & $0.84 \pm 0.06^{2}$ & $3.6 \pm 0.2$ & $0.33 \pm 0.03^{2}$ & $0.17 \pm 0.04^{2, a}$ & $0.77 \pm 0.03^{2}$ & $4.3 \pm 0.1^{2}$ \\
\hline \multirow[t]{2}{*}{ Radmilovcanka } & peel & $0.092 \pm 0.005^{\mathrm{c}}$ & $1.06 \pm 0.04^{b}$ & $9.3 \pm 0.2$ & $0.66 \pm 0.07^{b, c}$ & $0.19 \pm 0.06^{\mathrm{Ab}}$ & $0.88 \pm 0.04^{b}$ & $6.5 \pm 0.2$ \\
\hline & pulp & $0.077 \pm 0.003^{\mathrm{Aad}}$ & $1.57 \pm 0.06^{A}$ & $9.6 \pm 0.2^{2.2}$ & $0.62 \pm 0.03^{A}$ & $0.55 \pm 0.03^{\mathrm{B}}$ & $0.70 \pm 0.03^{A=}$ & $5.6 \pm 0.2^{2.6}$ \\
\hline \multirow[t]{2}{*}{ June Gold } & peel & $0.086 \pm 0.004^{A, e}$ & $1.65 \pm 0.04^{\mathrm{An} e}$ & $10.1 \pm 0.2^{A, b}$ & $0.73 \pm 0.06^{2 b, d}$ & $0.61 \pm 0.02^{\mathrm{B}}$ & $0.71 \pm 0.02^{\mathrm{abb}}$ & $5.7 \pm 0.2^{\wedge}$ \\
\hline & pulp & $0.081 \pm 0.003^{\mathrm{B}, 2}$ & $0.98 \pm 0.04^{d}$ & $9.6 \pm 0.2^{2}$ & $0.32 \pm 0.03^{2}$ & $0.15 \pm 0.01^{2}$ & $0.71 \pm 0.03^{\mathrm{B}, 2}$ & $4.2 \pm 0.2^{2}$ \\
\hline \multirow[t]{2}{*}{ Blake } & peel & $0.091 \pm 0.005^{\mathrm{B}, e}$ & $1.47 \pm 0.06$ & $13 \pm 2$ & $0.71 \pm 0.04^{b, e}$ & $0.20 \pm 0.02^{b}$ & $0.80 \pm 0.05^{B, b}$ & $7.2 \pm 0.2$ \\
\hline & pulp & $0.086 \pm 0.002^{C, a}$ & $0.85 \pm 0.07^{2 d}$ & $7.3 \pm 0.2^{e}$ & $0.36 \pm 0.04^{2 . f}$ & $0.128 \pm 0.008$ & $0.74 \pm 0.04^{c_{2}}$ & $1.45 \pm 0.07$ \\
\hline \multirow[t]{2}{*}{ Hale } & peel & $0.092 \pm 0.004^{c, e}$ & $1.16 \pm 0.07^{b}$ & $10.6 \pm 0.2^{b}$ & $0.79 \pm 0.04^{\mathrm{d}, e}$ & $0.31 \pm 0.02$ & $0.79 \pm 0.03^{c b}$ & $4.0 \pm 0.2$ \\
\hline & pulp & $0.111 \pm 0.006$ & $0.66 \pm 0.04^{e}$ & $7.5 \pm 0.2^{\mathrm{e}}$ & $0.32 \pm 0.02^{2}$ & $0.068 \pm 0.006^{\mathrm{e}}$ & $0.71 \pm 0.03^{2}$ & $5.2 \pm 0.2^{b}$ \\
\hline \multirow[t]{2}{*}{ Vesna } & peel & $0.126 \pm 0.006$ & $1.64 \pm 0.07^{e}$ & $10.6 \pm 0.2^{b}$ & $0.47 \pm 0.05$ & $0.095 \pm 0.004^{d}$ & $0.87 \pm 0.04^{b}$ & $9.6 \pm 0.3^{c}$ \\
\hline & pulp & $0.069 \pm 0.003^{b, d}$ & $0.61 \pm 0.04^{e}$ & $4.8 \pm 0.2$ & $0.46 \pm 0.04^{i}$ & $0.083 \pm 0.003^{C, e}$ & $0.76 \pm 0.05^{\mathrm{D}, a}$ & $7.2 \pm 0.2$ \\
\hline Adria & peel & $0.093 \pm 0.004^{e}$ & $1.31 \pm 0.05$ & $10.6 \pm 0.3^{b}$ & $0.59 \pm 0.03^{e}$ & $0.094 \pm 0.007^{c, d}$ & $0.78 \pm 0.04^{D, b}$ & $9.8 \pm 0.3^{\mathrm{c}}$ \\
\hline
\end{tabular}

SD-standard deviation for triplicate determination; mean values in the same column with the same capital letters indicate no significant differences ( $p<0.05$ ) between pulp and peel of the same cultivars; mean values in the same column with the same small letters indicate no significant differences ( $p<0.05$ ) between the pulps and between the peels of different cultivars, separately

an important role in nervous and muscle system and is important for the proper functioning of the heartand kidney; phosphorus is involved in the production of collagen; it is an integral part of the phospholipids that are located within the cell membrane, and the main component of adenosine triphosphate; it participates in the regulation of acid-base balance in the body together with sodium which is included in the circulation system helps the body keep blood pressure and the overall amount of blood at a normal level. United States Department of Agriculture recommended complete nutrient detailed table in USDA food composition table for item Peaches, raw natural number 09236 [1]. The recommended values for major minerals with recommended dietary intakes of nutrients for adults and children four or more years of age (Daily Value Percentage$\%$ DV) are as follows: Ca $60 \mathrm{mg} \mathrm{kg}^{-1}$ (6\%); Mg $90 \mathrm{mg} \mathrm{kg}^{-1}$ (22.5\%); P $200 \mathrm{mg} \mathrm{kg}^{-1}$ (20\%) and K $1900 \mathrm{mg} \mathrm{kg}^{-1}$ (54.29\%). DV, also referred to as RDI (Recommended Daily Intake) or nutritional RDA (Recommended Daily Allowance) or in some cases only as Al (Adequate Intake) average suggests the levels of intake of essential nutrients that sufficiently meet the nutritional requirements of healthy individuals. The results of one-way ANOVA analysis with Tukey's posthoc test show significant differences in the mean content of all investigated macroelements (table 1) between pulp and peel of peach fruits. In other w ords, regardless of the varieties of peach and available content of macroelements in the soil, there is a difference in content between peel and pulp. This is present to a lesser extent in the case of comparisons between the contents of these elements in the same part of the fruit of various species: the content of $\mathrm{Na}$ and $\mathrm{K}$ varies depending on the type of peach while the content of $P$ show the smallest differences between the same parts of different species. All examined macroelements are more present in the peel than in the pulp except for $K$ which is also the case in the work of Manzoor et al. and except $K$ and $P$ in the work of Basar suggesting the intake of unpeeled peach as a potential source of highvalue components [2,13]. $K$ is the most abundantelement in the both parts of fruits whose content ranges from 1822 $\mathrm{mg} \mathrm{kg}^{-1}$ to $6605 \mathrm{mg} \mathrm{kg}^{-1} \mathrm{WW}$ in the pulp and from $1223 \mathrm{mg}$ $\mathrm{kg}^{-1}$ to $5287 \mathrm{mg} \mathrm{kg}^{-1} \mathrm{WW}$ in the peel. The tested macroelements are mostly present in the following descending order: $\mathrm{K}>\mathrm{P}>\mathrm{Ca}>\mathrm{Na}>\mathrm{Mg}$ in all analyzed samples except some cases with the smallest amount of $\mathrm{Na}$ (peel and pulp of the samples Vesna and Adria). Manzoor et al. were determined the contents of $\mathrm{K}, \mathrm{Ca}$, and $\mathrm{Mg}$ in peel and pulp parts of three different varieties of peach fruit from Pakistan and significant differences were observed for each individual mineral [2]. Contents of determined elements follow next descending order: KÃMgÃCa in both parts of fruit. Basar determined $\mathrm{P}, \mathrm{N}, \mathrm{K}$, $\mathrm{Ca}$, and $\mathrm{Mg}$ in flesh and peel of three cultivars (Redhaven, Glohaven and J. H. Hale) from seven orchards in Turkey for each cultivar and these contents were similar in all of the cultivars and the amount of the elements in the same part did not significantly differ [13]. P and K were accumulated in significantly higher concentrations in pulp than in the peel unlike other determined elements. $\mathrm{K}$ and $\mathrm{N}$ were found below the sufficiency levels in the both flesh and peel samples while Ca content was only found deficient in the pulp samples according to Food and Agriculture Organization of the United Nations which reported critical values only for whole fruit. The order is as follows: $\mathrm{K}>\mathrm{N}>\mathrm{P}>\mathrm{Mg}>\mathrm{Ca}$ in both of the fruit parts which is the case in the work of Manzoor et al. [2]. Higher values of macroelements were detected in the aforementioned works because the fact that analyzed samples were ovendried at $70^{\circ} \mathrm{C}$ for $72 \mathrm{~h}$. Mean values of the three cultivars are: $0.17 \%$ and $0.12 \% \mathrm{P} ; 1.34 \%$ and $1.17 \% \mathrm{~K} ; 0.034 \%$ and $0.058 \% \mathrm{Ca} ; 0.062 \%$ and $0.078 \% \mathrm{Mg}$ in the pulp and peel,

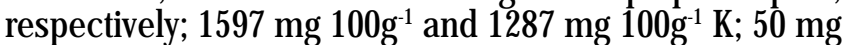

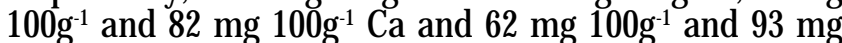
$100 \mathrm{~g}^{-1} \mathrm{Mg}[2,13]$. Differences ranging up to an order of magnitude which is in accordance with the percentage of water in the fruit peaches (about 88\%) [17]

Essential trace elements ( $\mathrm{B}, \mathrm{Fe}, \mathrm{Cu}, \mathrm{Zn}, \mathrm{Mn}, \mathrm{Ni}, \mathrm{Cr}$ ) in a certain amount are necessary for normal growth and development of plants and also for customers that use them in the diet. Manganese takes part in carbohydrates metabolism and is known as an antioxidant; iron is a core of red blood cells; zinc is reported as a coenzyme for over 200 enzymes and its sufficient is essential to neutralize the toxic effects of cadmium and excessive absorption of zinc suppresses copper and iron absorption; copper as biocatalyst is an essential trace element, necessary for body pigmentation, for maintenance of a healthy central nervous system, prevention of anemia but its toxicity is a much overlooked contributor to many health problems; nickel is involved in iron metabolism (it affects the absorption of iron from foods) and plays the important role in the formation of red blood cells; it is necessary in the metabolism of sugars, fats, hormones, and cell membranes; chromium helps the metabolism of glucose, regulates the level of insulin and maintain healthy levels of cholesterol and other fats in the blood; boron is important 


\begin{tabular}{ccccc}
\hline Varieties & $\begin{array}{c}\text { Fruit } \\
\text { part }\end{array}$ & $\mathrm{Al}$ & $\mathrm{As}$ & $\mathrm{Pb}$ \\
& pulp & $2.7 \pm 0.2$ & $0.041 \pm 0.003$ & $0.012 \pm 0.001^{\mathrm{a}}$ \\
Radmilovcanka & peel & $7.4 \pm 0.3$ & $0.051 \pm 0.004$ & $0.015 \pm 0.001^{\mathrm{b}}$ \\
& pulp & $5.2 \pm 0.2$ & $0.050 \pm 0.003^{\mathrm{a}}$ & $0.015 \pm 0.001^{\mathrm{A}}$ \\
June Gold & peel & $12.4 \pm 0.5$ & $0.071 \pm 0.003^{\mathrm{b}}$ & $0.016 \pm 0.002^{\mathrm{A}} \mathrm{b}$ \\
& pulp & $4.0 \pm 0.2$ & $0.049 \pm 0.003^{\mathrm{a}}$ & $0.023 \pm 0.003$ \\
Blake & peel & $13.8 \pm 0.3$ & $0.070 \pm 0.002^{\mathrm{b}}$ & $0.026 \pm 0.002$ \\
& pulp & $7.5 \pm 0.2$ & $0.063 \pm 0.002$ & $0.020 \pm 0.002^{\mathrm{B}}$ \\
Hale & peel & $9.1 \pm 0.3$ & $0.068 \pm 0.003^{\mathrm{b}}$ & $0.021 \pm 0.002^{\mathrm{B}}$ \\
& pulp & $3.1 \pm 0.2$ & $0.034 \pm 0.002^{\mathrm{A}}$ & $0.009 \pm 0.001^{\mathrm{C}, \mathrm{a}}$ \\
Vesna & peel & $4.9 \pm 0.2$ & $0.036 \pm 0.002^{\mathrm{A}}$ & $0.010 \pm 0.001^{\mathrm{C}, \mathrm{c}}$ \\
& pulp & $6.5 \pm 0.2$ & $0.037 \pm 0.002$ & $0.009 \pm 0.001^{\mathrm{D}, \mathrm{a}}$ \\
Adria & peel & $7.5 \pm 0.2$ & $0.045 \pm 0.003$ & $0.010 \pm 0.001^{\mathrm{D}, \mathrm{c}}$ \\
\hline
\end{tabular}

Table 3

THE CONTENT OF POTENTIALLY TOXIC AND TOXIC ELEMENTS $\pm \mathrm{SD}^{\mathrm{A}}\left(\mathrm{mg} \mathrm{kg}^{-1} \mathrm{WW}\right)$ IN PEEL AND PULP PARTS OF PEACH FRUIT for maintaining healthy bones and joints, it influences the metabolism of steroid hormones, and likely plays a role in the conversion of vitamin $D$ to the active form and also increases the level of male sex hormones. The recommended values for trace minerals with \% DV are as follows: Cu $0.68 \mathrm{mg} \mathrm{kg}^{-1}$ (34\%); Fe $2.5 \mathrm{mg} \mathrm{kg}^{-1}$ (13.89\%); Mn $0.61 \mathrm{mg} \mathrm{kg}^{-1}$ (30.5\%) and Zn $1.7 \mathrm{mg} \mathrm{kg}^{-1}$ (11.33\%) [1]. Fe is the most common essential trace element in all analyzed samples whose content ranges from $3.6 \mathrm{mg}$ $\mathrm{kg}^{-1}$ to $9.6 \mathrm{mg} \mathrm{kg}^{-1}$ in pulp and from $9.3 \mathrm{mg} \mathrm{kg}^{-1}$ to $13 \mathrm{mg}$ $\mathrm{kg}^{-1}$ in peel. It is also the element with the greatest differences between peel and pulp except in the case of varieties] une Gold. Also, there is no statistically significant difference in the contents of iron in the peel of almost all investigated species which is not the case with the pulp. Also, the content of Cu does not differ statistically significant only in the peel and pulp of J une Gold unlike other species. The examined types of peaches less differ in Cu content in the pulp than in the peel. The behavior of $\mathrm{Zn}$ is interesting. In fact, there is no difference in content between the peel and the pulp of four studied species as well as between the same parts of all studied species. J une gold is allocated also in the case of $\mathrm{Mn}$. In all other species there is a significant difference between the peel and the pulp of the same species. The greatest number of the examined species is no different in the content of this element in the peel and in the pulp. $B$ is the second microelement according to presence and only in J une gold is no difference between the peel and the pulp. Also, the almost varieties have different content of $B$ in the peel and in the pulp. Ni and $\mathrm{Cr}$ are the least represented in all samples and the smallest differences between the peel and the pulp exists in the case of these trace metals. Also, examined types of peaches are differentiated by the content of $\mathrm{Ni}$ in both parts of the fruit, unlike $\mathrm{Cr}$. Generally, the contents of examined trace elements follow the next descending order: $\mathrm{Fe}>\mathrm{B}>\mathrm{Cu}>\mathrm{Zn}>\mathrm{Mn}>\mathrm{Ni}>\mathrm{Cr}$ in the peel and the pulp of almost all the samples. Manzoor et al. were determined the contents of $\mathrm{Mn}, \mathrm{Fe}$, and $\mathrm{Zn}$ and the contents of determined elements follow next descending order: FeÃMnÃZn in both parts of fruit [2]. The contents of these trace metals were even ten times higher ( $\mathrm{Mn}$ from 0.41 to

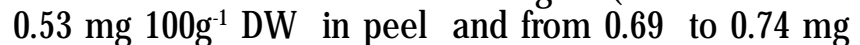

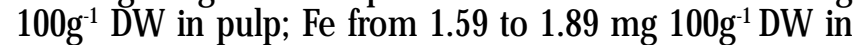

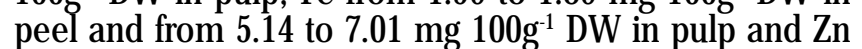

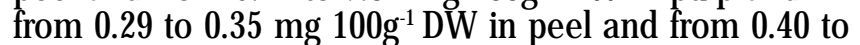

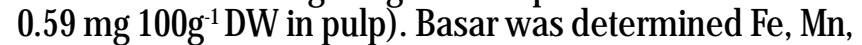
$\mathrm{Zn}, \mathrm{Cu}, \mathrm{Cr}, \mathrm{Co}$, and $\mathrm{Ni}$ in the pulp and the peel in three cultivars and these contents were similar in all of the cultivars and the amount of the elements were not significantly differ except $\mathrm{Co}$ in the pulp and Fe in the peel [13]. This fact author explained by the specific distribution of these nutrients in plants parts. The concentrations of Fe, $\mathrm{Mn}, \mathrm{Zn}, \mathrm{Cu}, \mathrm{Co}$ and $\mathrm{Cr}$ were found at normal ranges in both of the fruit parts according to Food and Agriculture
Organization of the United Nations. Ni concentrations were above the tolerable levels in the both fruit peel and pulp. Examined elements follow the next descending order: $\mathrm{Fe}>\mathrm{Zn}>\mathrm{Cu}>\mathrm{Mn}>\mathrm{Ni}>\mathrm{Co}>\mathrm{Cr}$ in the pulp and in the peel: $\mathrm{Fe}>\mathrm{Cu}>\mathrm{Zn}>\mathrm{Mn}>\mathrm{Ni}>\mathrm{Co}>\mathrm{Cr}$. The average amounts in the pulp are as follows: Fe $12.53 \mathrm{mg} \mathrm{kg}^{-1} ; \mathrm{Mn} 3.29 \mathrm{mg} \mathrm{kg}^{-1} ; \mathrm{Zn}$ $7.47 \mathrm{mg} \mathrm{kg}^{-1}$; Cu $6.42 \mathrm{mg} \mathrm{kg}^{-1}$; Cr $0.20 \mathrm{mg} \mathrm{kg}^{-1}$; Ni $1.66 \mathrm{mg}$ $\mathrm{kg}^{-1}$; Co $0.45 \mathrm{mg} \mathrm{kg}^{-1}$; while in peel samples: Fe $41.82 \mathrm{mg}$ $\mathrm{kg}^{-1}$; Mn $4.76 \mathrm{mg} \mathrm{kg}^{-1}$; Zn $8.26 \mathrm{mg} \mathrm{kg}^{-1}$; Cu $9.83 \mathrm{mg} \mathrm{kg}^{-1}$; Cr $0.32 \mathrm{mg} \mathrm{kg}^{-1}$; Ni $1.78 \mathrm{mg} \mathrm{kg}^{-1}$; Co $0.48 \mathrm{mg} \mathrm{kg}^{-1}$.

Lead has neurological effects on human health, especially the younger population; cadmium is carcinogen for human and toxic to plants; arsenic accumulates in the body, especially in the hair, skin and some internal organs and inorganic trivalentarsenic is particularly toxic; mercury is a powerful neurotoxin and it can cause damage to the brain, kidneys and lungs and is especially dangerous for pregnant women and children. The maximum allowable concentrations (MAC values) of $\mathrm{Pb}, \mathrm{Cd}, \mathrm{Hg}$ and $\mathrm{As}$ in fresh fruits ( $1,0.05,0.02$ and $0.1 \mathrm{mg} \mathrm{kg}^{-1}$, respectively) are defined by national regulation: The provisions on maximal allowed amounts of pesticides, metals, metalloids and other toxic substances, chemotherapeutics, anabolics and other substances that can be found in food [18]. $\mathrm{Hg}$ and $\mathrm{Cd}$ are not detected while the contents of $\mathrm{Pb}$ and $\mathrm{As}$ are below these values in all tested samples. The contents of As and $\mathrm{Pb}$ are ranged from 0.034 to $0.070 \mathrm{mg} \mathrm{kg}^{-1}$ and from 0.009 to $0.026 \mathrm{mg} \mathrm{kg}^{-1}$, respectively, and the less differences in content between the parts of the fruit as well as betw een the tested varieties are obvious, especially for $\mathrm{Pb}$. The content of Al is greater in the peel of all samples then in pulp even more than three times. It is also evident that all the analyzed peach varieties show statistically significantly differences regarding the content of this element. Maximum levels (MLs) for heavy metals in foodstuffs have been set by Commission Regulation [8]. The European Communities set maximum levels (MLs) to be $0.10 \mathrm{mg}$ $\mathrm{kg}^{-1} \mathrm{WW}$ for $\mathrm{Pb}$ and $0.05 \mathrm{mg} \mathrm{kg}^{-1}$ for $\mathrm{Cd}$. There are no statutory limits for As and $\mathrm{Hg}$ levels in fruit at EU level. Basar determined significantly higher concentrations, as average amounts, of $\mathrm{Pb}\left(1.67 \mathrm{mg} \mathrm{kg}^{-1} \mathrm{DW}\right)$ in pulp then in peel samples $\left(0.56 \mathrm{mg} \mathrm{kg}^{-1} \mathrm{DW}\right)$ and these concentrations were above the tolerable levels in the both fruit parts [13]. Matei et al. found $0.0228 \mathrm{mg} \mathrm{kg}^{-1} \mathrm{Cd}$ in whole fruit while lead is not detected while Chistayokov et al. found 0.01 $\mathrm{mg} \mathrm{kg}^{-1} \mathrm{Cd}$ in Egypt samples of whole peach fruit $[2,19]$.

\section{Conclusions}

The assessment of metals in peach represents one of the factors in the evaluation of their quality. In the present work, the minerals of different parts (peel and pulp) of six varieties of peach fruit were evaluated. $K$ is the most abundant macroelement in the both parts of fruits while $\mathrm{Fe}$ is the most common essential trace element. All 
examined macroelements are more present in the peel than in the pulp with the exception of $\mathrm{K}$ which is also the case in the earlier works. It follows that removal of peel from peach fruits may induce significant nutrient losses and because of that the intake of fruits along with their peels can be more beneficial as a potential source of highvalue components. Significant differences in the mean content of all investigated macroelements between the pulp and the peel of peach fruits in all investigated cultivars exist. Differences in the metals content in the same part of the fruit of different species are smaller and at least in the case of $P$. The tested macroelements are present in the following descending order: $\mathrm{K}>\mathrm{P}>\mathrm{Ca}>\mathrm{Na}>\mathrm{Mg}$ and the contents of examined trace elements follow the next descending order: $\mathrm{Fe}>\mathrm{B}>\mathrm{Cu}>\mathrm{Zn}>\mathrm{Mn}>\mathrm{Ni}>\mathrm{Cr}$ in the peel and the pulp of almost all samples. Much smaller differences in the content of trace elements between the peel and the pulp of the same species and between different parts of the same type are present. $\mathrm{Hg}$ and $\mathrm{Cd}$ are not detected while the contents of $\mathrm{Pb}$ and $\mathrm{As}$ are below values prescribed by relevant regulations. On the base of obtained results and recommendations of USDA it can be said that this fruit can serve as a good source of essential metals for humans.

Acknowledgement: This research was supported by the grant numbers 172047 of the Ministry of Education, Science and Technological Development of Serbia. The authors are grateful for the financial support provided by this Ministry.

\section{References}

1. *** U. S. Department of Agriculture, Agricultural Research Service, USDA Food Composition Databases, The food item Peaches, raw natural number 09236, 2016

2. MANZOOR, M., ANWAR, F., MAHMOOD, Z., RASHID, U., ASHRAF, M., Molecules, 17, no. 6, 2012, p. 6491

3. MATEI, N., POPESCU, A., MUNTEANU, M., LUCIAN RADU, G., University Politehnica of Bucharest, Scientific Bulletin, Series B, 75, no. 1, 2013, p. 73
4. KABATA-PENDIAS, A., Trace elements in soils and plants, 4 edition, CRC Press Taylor and Francis Group, Boca Raton, London, New York, 2010, p.14

5. ALSHAMMARY, S. F., AL-HORAYESS, O. S., Oriental J ournal of Chemistry, 29, no. 4, 2013, p. 1515

6. LIN, Y. F., AARTS, M. G., Mol. Life Sci., 69, no. 19, 2012, p. 3187

7. RADWAN, M. A., SALAMA, A. K., Food and Chemical Toxicology, 44, no. 8,2006, p. 1273

8.*** European Commission, Commission Regulation (EC) No 1881, setting maximum levels for certain contaminants in foodstuffs, Official Journal of the European Communities L364/5, 2006

9. ELBAGERMI, M. A., EDWARDS, H. G. M., ALAJ TAL, A. I., International Scholarly Research Network, Analytical Chemistry, 10, 2012, p. 1

10. CUNNINGHAM, J. H., MILLIGAN, G., TREVISAN, L., Canberra: Food Standars Australia New Zealand, 2004, electronic book https:// www.foodstandards.gov.au/publications/documents/minerals_ report.doc

11. ACAR, 0., Eurasian J. Anal. Chem., 6, no. 2, 2011, p. 114

12. TORMEN, L., TORRES, D. P., DITTERT, I. M., ARAUJ O, R. G. O., FRESCURA, V. L. A., CURTIUS, A. J., Food Comp. Anal., 24, no. 1, 2011, p. 95

13. BASAR, H., Sci. Hort., 107, no. 3, 2006, p. 259

14. RADOJEVIC, M., BASHKIN, V., Practical Environmental Analysis, The Royal Society of Chemistry, Cambrige, UK, 1999, p. 378

15. MILLER, J. N. MILLER, J. C., Statistics and Chemometrics for Analytical Chemistry, Pearson Education Limited, London, UK, 2005, p. 15*** World Health Organization, Trace Elements in Human Nutrition and Health, Geneva, 1996

17. MAYER, A. M., Brit. Food J., 99, no.6, 1997, p. 207

18.*** The Official Gazette of the Republic of Serbia, No. 5/92, 11/92, $32 / 2002,25 / 2010$ and 28/2011, The provisions on maximal allowed amounts of pesticides, metals, metalloids and other toxic substances, chemotherapeutics, anabolics and other substances that can be found in food (in Serbian).

19. CHISTAYOKOV, V. A., VODOLAZHSKII, D. I., TIMOSHKINA, N. N., VOINOVA, N. V., Russ. J. Ecol., 33, no. 4, 2002, p. 296

Manuscript received: 17.08 .2018 